Doskočıl, J., Sikyta, B., Kašparová, J., Doskočılová, D. \& ZaJł́̌̌ek, J. (1958). J. gen. Microbiol. 18, 302-314

\title{
Development of the Culture of Streptomyces rimosus in Submerged Fermentation
}

\author{
BY J. DOSKOČIL, B. SIKYTA, JITKA KAŠPAROVA, DANICA \\ DOSKOČILOVA AND J. ZAJÍCEK
}

Antibiotics Research Institute, Roztoky near Prague, Czechoslovakia

\begin{abstract}
SUMMARY: The development of Streptomyces rimosus in submerged culture, in a medium containing starch, glucose, ammonium sulphate, corn-steep liquor and calcium carbonate, takes place in several phases which differ in their morphological and biochemical characteristics. The starting phase is characterized by the logarithmic growth of thick Gram-positive filaments of the primary mycelium. Nucleic acids and respiratory enzymes are being synthesized during this phase and free amino acids and inorganic phosphorus in the medium are being almost completely used up. A considerable amount of pyruvic acid is being produced and accumulated in the medium. No production of oxytetracycline and pigments takes place. In the phase of logarithmic growth the respiration of the culture reaches a maximum value of 500-700 ml. $\mathrm{O}_{2} / 1 / \mathrm{hr}$; ; this stage growth of the primary mycelium ceases and its hyphae undergo fragmentation. Pyruvic acid, which had accumulated in the medium in the phase of logarithmic growth, is rapidly used up during the fragmentation period. From the fragments of the primary mycelium long Gram-negative filaments of secondary mycelium start growing. Growth in this phase is accompanied neither by any significant increase of the respiration nor by excretion of pyruvic acid; deoxyribonucleic acid (DNA) synthesis is considerably slower than in the phase of logarithmic growth and the total amount of ribonucleic acid (RNA) is decreasing; oxytetracycline and pigments are being produced both by the growing secondary mycelium and in the subsequent stationary phase.
\end{abstract}

During the growth and development of actinomycetes morphological and physiological changes take place, both in surface cultures (Klieneberger-Nobel, 1947) and in submerged cultures (Carvajal, 1947; Biff, Boretti, Di Marco \& Pennella, 1954; Scotti \& Zocchi, 1955; Baldacci, 1956). The development of the culture takes place in roughly two phases: in the first phase long hyphae develop from the spores; these hyphae undergo fragmentation or sporulation; the fragments or spores give rise to the hyphae of the second generation. Similar morphological changes take place also during the growth of Streptomyces rimosus, a producer of the antibiotic oxytetracycline (ProkofievaBelgorskaya, Pestiereva \& Rudaya, 1956). A biochemical characterization of the development of this species has so far not been presented; very little information is available especially about the factors which determine the existence and transition of the growth phases. Knowledge of these factors is important not only for our understanding of the physiology of the actinomycetes, but also from the practical standpoint; it enables us to predict the development of the culture and to control it by purposeful combinations of medium composition and other cultivation conditions. Knowledge of these factors which limit growth and determine the transition of one phase into the 
other is indispensable in experiments concerning the possibility of continuous fermentation.

The aim of the present communication is the description of the development of Streptomyces rimosus in submerged culture and a biochemical and morphological characterization of the main phases of its development.

\section{METHODS}

Organism. A strain of Streptomyces rimosus from the collection of the Antibiotics Research Institute, Roztoky near Prague, was used.

Medium. The organism was cultivated on a modified medium described by Nečásek \& Lokvenc (1956) of the following composition: $1 \%(w / v)$ technical grade glucose; $1.9 \%(\mathrm{w} / \mathrm{v})$ potato starch; $1 \%(\mathrm{w} / \mathrm{v})$ corn-steep liquor; $0.6 \%$ $(\mathrm{w} / \mathrm{v})$ ammonium sulphate; $0.8 \%(\mathrm{w} / \mathrm{v})$ calcium carbonate; $0.5 \%(\mathrm{w} / \mathrm{v})$ sodium chloride; $0.2 \%(\mathrm{v} / \mathrm{v})$ soybean oil as antifoam. The $\mathrm{pH}$ value of the medium before sterilization was adjusted to 6.0 , after sterilization $\left(115^{\circ}, 30 \mathrm{~min}\right.$.) it was $\mathrm{pH} 6 \cdot 5-6 \cdot 8$. An analysis of the medium is given in Table 1 .

\section{Table 1. Analysis of the culture medium}

\begin{tabular}{|c|c|}
\hline Reducing substances after hydrolysis (as glucose) & $35 \cdot 7-40.5 \mathrm{mg} . / \mathrm{ml}$. \\
\hline Free reducing sugars (as glucose) & $7 \cdot 7-8.9 \mathrm{mg} . / \mathrm{ml}$ \\
\hline Keto acids (as $\mathrm{Na}$ pyruvate) & $24-30 \mu \mathrm{g} . / \mathrm{ml}$ \\
\hline Neutral carbonyl compounds (as glyceraldehyde) & $190-200 \mu \mathrm{g} . / \mathrm{ml}$ \\
\hline Total nitrogen & $1.82-2.17 \mathrm{mg} . / \mathrm{ml}$. \\
\hline Ammonia nitrogen & $1 \cdot 12-1.33 \mathrm{mg} . / \mathrm{ml}$. \\
\hline$\alpha$-Amino nitrogen & $0.44-0.47 \mathrm{mg} . / \mathrm{ml}$ \\
\hline Total phosphorus & $250-300 \mu \mathrm{g} . / \mathrm{ml}$ \\
\hline Soluble phosphorus & $82-84 \mu \mathrm{g} . / \mathrm{ml}$ \\
\hline Inorganic phosphorus & $44-48 \mu \mathrm{g} . / \mathrm{ml}$ \\
\hline Inorganic soluble phosphorus & 24-28 $\mu \mathrm{g} . / \mathrm{ml}$. \\
\hline
\end{tabular}

Note. The neutral carbonyl compounds came from the technical grade glucose used.

Cultivation. Growth of the organism was carried out in 20 l. stainless-steel laboratory fermentation vessels of $10 \mathrm{l}$. effective capacity. The medium was aerated with $0.5 \mathrm{vol}$. of air $/ \mathrm{min}$. and stirred at $300 \mathrm{rev} . / \mathrm{min}$. The rate of oxygen transfer as measured by the sulphite oxidation was $1500 \mathrm{ml} . \mathrm{O}_{2} / \mathrm{l}$. $/ \mathrm{hr}$. The temperature during growth was maintained at $28^{\circ}$. The vegetative inoculum for the seed-tank was prepared in flasks on a reciprocating shaking machine by a procedure according to Nečásek \& Lokvenc (1956). The seedtank was inoculated by $30-50 \mathrm{ml}$. of a $24 \mathrm{hr}$-inoculum from a flask. The production tank was seeded with $10 \%(\mathrm{v} / \mathrm{v})$ of the inoculum from the seed-tank; the appropriate inoculation age of the seed was determined by the measurement of the respiration of the culture. A culture with a respiration of $300-$ $500 \mathrm{ml} . \mathrm{O}_{2} / \mathrm{l}$./hr. was usually used for inoculation; this value was reached between 16 and $22 \mathrm{hr}$. of growth in the seed-tank.

Analytical methods. The production of oxytetracycline was determined by the colorimetric method (Monastero, Means, Grenfell \& Hedger, 1951). Total carbohydrate was determined after acid hydrolysis by the method of Bertrand, 
free reducing sugars also by the method of Bertrand. The $\alpha$-amino nitrogen was determined according to Schroeder, Kay \& Mills (1950), the ammonia nitrogen by steam distillation in the presence of magnesium oxide and titration of the distillate according to Cole \& Parks (1949). Total nitrogen after kjeldahlization of the sample was determined colorimetrically with the Nessler reagent (Umbreit, Burris \& Stauffer, 1951). Keto acids were determined according to Friedemann \& Haugen $(1942,1943)$. Qualitative differentiation of keto acids was carried out by paper electrophoresis of their $2: 4$-dinitro-phenylhydrazones (Tauber, 1955). Dry weight of mycelium was determined by centrifugation of $10 \mathrm{ml}$. culture, resuspension of the sedimented mycelium in water acidified by hydrochloric acid to $\mathrm{pH}$ c. 1.5 (for dissolution of calcium carbonate), washing with water, twice with acetone and drying at $100^{\circ}$ to constant weight. Washing with acetone was necessary in order to remove oil added to the culture as antifoam.

Nucleic acids were extracted from the mycelium by perchloric acid according to Ogur \& Rosen (1950). The concentration of nucleic acids was determined spectrophotometrically on the Universalspektrofotometer Zeiss. We noted that the extracts of deoxyribonucleic acid (DNA) showed an absorption maximum at wavelengths somewhat higher than those given by Ogur \& Rosen for standard preparations of DNA. Ribonucleic acid (RNA) was determined by measurement of the extinction at $260 \mathrm{~m} \mu$., DNA at $274 \mathrm{~m} \mu$. directly, in appropriately diluted extracts against solutions of perchloric acid of equal concentration. For verification of the method the concentration of total phosphorus was determined in several samples by the method of Fiske \& SubbaRow (1925) and the value of specific extinction/mole of phosphorus, $\epsilon(\mathrm{P})$, was calculated. $\epsilon(\mathrm{P})$ is defined as: $\epsilon(\mathrm{P})=30 \cdot 98 E / c l$, where $E$ is the extinction measured, $c$ is the concentration of phosphorus in $\mathrm{g} . / \mathrm{l}$. and $l$ is the thickness of the liquid layer in $\mathrm{cm}$. For RNA the value $\epsilon(\mathbf{P})=9590$ with a standard deviation of $\pm 6 \cdot 6 \%$ was found as an average of 17 determinations made between 12 and $72 \mathrm{hr}$. of growth. This value is within the limits of the variation of the values given in the literature for RNA isolated from various sources. For DNA a value of $\epsilon(\mathrm{P})=5700$ with a standard deviation of $\pm 6 \cdot 1 \%$ was found, this being somewhat less than the values published for various preparations of DNA (Chargaff \& Davidson, 1955, cite values from 6000 to $\mathbf{8 0 0 0}$ ). Determinations of nucleic acids were reproducible within the limits of $\pm \mathbf{2 - 3} \%$ in extracts prepared independently from the same starting material.

The respiration of the mycelium was determined both by the direct Warburg method and polarographically. The data were obtained usually by the polarographic method, because it was more rapid than respirometry and very frequent measurements of the respiration were possible. In polarographic measurements we followed the method of Umbreit et al. (1951) modified for the measurement of the respiration of suspensions of actinomycetes. Determinations were carried out in a respirometric Warburg vessel without the central well, with a side arm provided with a bored stopper. The vessel, brimful with the diluted suspension of the mycelium saturated with air and brought to $25^{\circ}$, was attached to the rubber stopper carrying the mercury dropping- 
electrode and a reference antimony anode. The temperature $25^{\circ}$ was chosen in order to avoid the necessity of working in a thermostat, which would greatly have prolonged the measurements. The electrodes were polarized by a constant potential difference of $300 \mathrm{mV}$., branched off from a Kohlrausch bridge. The current passing through the cell, proportional to the instantaneous concentration of oxygen, was measured by a galvanometer of the sensitivity of $7 \cdot 1 \times 10^{-9} \mathrm{~A}$./mm.; the sensitivity was regulated by an Ayrton shunt. The instrument was calibrated by a solution of $0.01 \mathrm{~N}-\mathrm{KCl}$ saturated with air. Current intensity was read every 30 sec. The contents of the cell, which had to be free from air bubbles, was stirred by a magnetic stirrer between the readings. As the consumption of oxygen in a fully developed culture was too rapid, the native suspensions had to be diluted (up to sixfold) with sterile culture medium. Respiration of the mycelium was calculated from the slope of the straight line corresponding to the depletion of oxygen in the vessel multiplied by the dilution. The results of parallel polarographic determinations from the same material were reproducible to $\pm 5 \%$. A series of parallel polarographic and manometric determinations showed a good agreement of the results of both methods.

Values of $\mathrm{pH}$ were measured with a glass electrode on a $\mathrm{pH}$ meter RFT type 158.

The morphology of the mycelium was followed in microscopic preparations stained by Gram's method. The results given in the following section are based on analyses of the growth of fifteen batches, of which seven were inoculated by $0.3-0.5 \%(\mathrm{v} / \mathrm{v})$ of vegetative inoculum from a flask and eight were inoculated by $10 \%(\mathrm{v} / \mathrm{v})$ of vegetative inoculum from a seed-tank. Unless the contrary is stated, the characters of all cultures agreed within the limits stated below.

\section{RESULTS}

The development of the culture in the seed-tank when inoculated by a small amount $(0 \cdot 3-0.5 \%, \mathrm{v} / \mathrm{v})$ of a vegetative inoculum begins by a period lasting several hours, in which it is not possible to detect any changes in the culture by any of the methods mentioned above. The start of the growth can nevertheless be characterized indirectly by analyses of the inoculum used. A $24 \mathrm{hr}$. culture of the 2nd vegetative stage from flasks had a consumption of oxygen about $50-100 \mathrm{ml} . \mathrm{O}_{2} / \mathrm{l} / \mathrm{hr}$., so that with an inoculation ratio of $0 \cdot 3-0 \cdot 5 \%(\mathrm{v} / \mathrm{v})$ the growth started with an $\mathrm{O}_{2}$-uptake of $0 \cdot 15-0.50 \mathrm{ml} . \mathrm{O}_{2} / \mathrm{l} . / \mathrm{hr}$.

After 12-15 hr. of growth in the seed-tank a considerable increase of the dry weight of the mycelium took place, accompanied by a parallel increase of $\mathrm{O}_{2}$-uptake. The consumption of oxygen in this phase can be measured accurately and quickly, and is therefore best suited for a quantitative characterization of the development of the culture during this period. Measurements of $\mathrm{O}_{2}$-uptake at $30 \mathrm{~min}$. intervals showed that $\mathrm{O}_{2}$-uptake during the first period of this stage increased logarithmically. It can be seen (Fig. 1) that by extrapolation of the experimental values of respiration the duration of the lagphase may be roughly estimated. This extrapolation gives a value of $c .90 \mathrm{~min}$. 
The exact length of the lag-phase cannot be determined since criteria for its direct measurement are not experimentally accessible. From Fig. 1 the time required for doubling the $\mathrm{O}_{2}$-uptake, i.e. a value analogous to the mean generation time, can be determined, being equal to $89 \mathrm{~min}$. at $28^{\circ}$. The dry weight of the mycelium also increased exponentially, but its determination

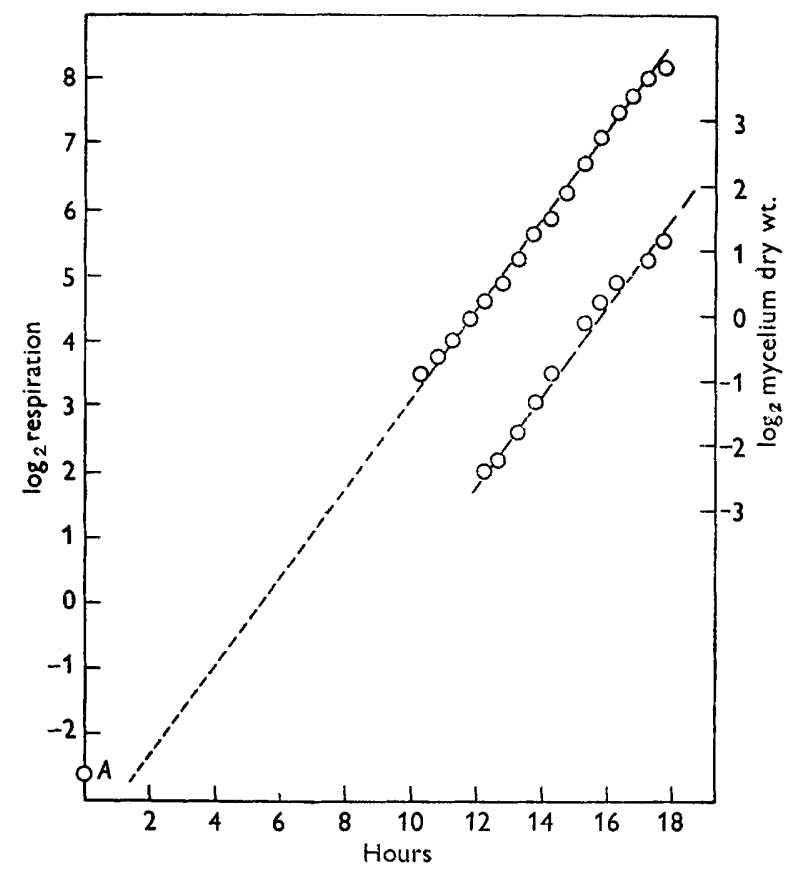

Fig. 1. Stage of logarithmic growth of a submerged culture of Streptomyces rimosus. The medium was inoculated with $0 \cdot 16 \%(\mathrm{v} / \mathrm{v})$ of a vegetative inoculum. Upper curve: logarithm of $\mathrm{O}_{2}$-uptake. Lower curve: logarithm of dry wt. mycelium $/ \mathrm{ml}$. Point $A$ gives the $\mathrm{O}_{2}$-uptake of the culture at inoculation; this value was calculated from the $\mathrm{O}_{2}$-uptake of the inoculum.

was less exact than that of $\mathrm{O}_{2}$-uptake. The metabolic coefficient $\boldsymbol{Q}_{\mathrm{o}_{2}}$ therefore remained nearly constant during this period and was equal to $137 \mathrm{ml} . \mathrm{O}_{2} / \mathrm{g}$. dry wt. mycelium/hr., on the average.

Nucleic acids were synthesized at a rate parallel to the increase in $\mathbf{O}_{2}$-uptake and dry wt. mycelium. The amount of RNA synthesized during the stage of logarithmic growth varied in different batches of culture from 240 to $560 \mu \mathrm{g} . / \mathrm{ml}$. The amount of DNA varied between 220 and $270 \mu \mathrm{g} . / \mathrm{ml}$. At the end of the logarithmic growth stage the amount of DNA was always lower than the amount of RNA, although their ratio was not constant. The amount of RNA/ unit dry wt. mycelium reached a maximum of $8-12 \%(\mathrm{w} / \mathrm{w})$ at the end of the logarithmic stage, the amount of DNA then being 5-6\%.

Some of the components of the medium were used up almost completely during the period of logarithmic growth. The concentration of $\alpha$-amino nitrogen decreased from the original $0 \cdot 44-0.47 \mathrm{mg}$. $/ \mathrm{ml}$. to $0 \cdot 05-0 \cdot 10 \mathrm{mg} . / \mathrm{ml}$. and remained at that level until the end of the cultivation; the concentration 
of inorganic phosphate decreased from the original $24-28 \mu \mathrm{g} . / \mathrm{ml}$. to $5-6 \mu \mathrm{g} . / \mathrm{ml}$. From the total original amount of ammonia nitrogen $(1.12-1.33 \mathrm{mg} . / \mathrm{ml}$.) c. $0 \cdot 3-0 \cdot 4 \mathrm{mg} . / \mathrm{ml}$. were used up in this period, so that ammonia is quantitatively about as important a source of nitrogen as amino acids. The amount of total carbohydrate decreased by about $16 \mathrm{mg} . / \mathrm{ml}$., whereas the amount of free reducing sugars underwent much less change; reducing sugar was continually being formed from starch by the amylolytic enzymes from the mycelium, so that its concentration remained nearly constant until complete exhaustion of starch.

The increase of the concentration of pyruvate was a very characteristic feature of the stage of logarithmic growth, being completely parallel with the increase in $\mathrm{O}_{2}$-uptake. The concentration of pyruvate increased to 800 $1300 \mu \mathrm{g} . / \mathrm{ml}$. at $8-12 \mathrm{hr}$. in production tanks, and at 20-25 hr. in the seedtanks. After reaching this maximum value it decreased again very rapidly (Figs. 2, 4). Consumption of ammonia and formation of pyruvic acid was the cause of the decrease of $\mathrm{pH}$ values from $6 \cdot 8$ to $6 \cdot 3$, at which value the culture remained during the rest of the period of cultivation. Microscopically the cultures showed, during the stage of logarithmic growth, a great proportion of long thick Gram-positive filaments and a negligible proportion of disintegrated filaments which were also Gram-positive; very occasionally a few thin Gramnegative filaments may also be observed. In the stage of logarithmic growth the mycelium was white and did not produce oxytetracycline; the first traces of oxytetracycline and pigments began to appear after the maximum concentration of keto acids has been passed.

Logarithmic growth ceased when the $\mathrm{O}_{2}$-uptake reached $500-700 \mathrm{ml} . \mathrm{O}_{2} / 1 . / \mathrm{hr}$. Growth of the mycelium greatly slowed or even ceased, and $\mathrm{O}_{2}$-uptake and $Q_{\mathrm{O}_{2}}$ decreased slightly. The rate of utilization of carbohydrate and ammonia-N did not decrease measurably in normal cultures, where this stage was relatively short. When, however, this stage was artificially prolonged, e.g. by interrupted aeration in the previous stage of logarithmic growth, a distinct lag was observed in the curves of carbohydrate and ammonia- $N$ consumption, this lag corresponding to the lag in the growth curve. The concentration of pyruvate decreased from $800-1300 \mu \mathrm{g} . / \mathrm{ml}$. to $20-70 \mu \mathrm{g} . / \mathrm{ml}$. The amount of RNA in this stage decreased, whereas DNA continued to increase, although considerably more slowly than in the stage of logarithmic growth.

Microscopically a complete fragmentation of the thick filaments may be observed in the period after the cessation of logarithmic growth. We therefore designate this stage as that of the fragmentation of primary mycelium.

Under normal conditions of cultivation the stage of fragmentation of primary mycelium lasts $c .10 \mathrm{hr}$. After this period the dry wt. mycelium/ml. begins to increase again and reaches a value of $8-18 \mathrm{mg} . / \mathrm{ml}$. during the following $25 \mathrm{hr}$. The mycelium grown-up in this phase differs profoundly from the primary mycelium growing in the logarithmic phase. The growth of this secondary mycelium was not accompanied by any significant increase of respiration of the culture, so that $Q_{\mathrm{O}_{2}}$ values dropped sharply to $20-50 \mathrm{ml}$. $\mathrm{O}_{2} /$ g. dry wt. mycelium/hr. No RNA was then being synthesized and its 
total amount was decreasing. The total amount of DNA continued to increase slowly but not in proportion to the amount of the newly formed secondary mycelium, so that also the amount of $\mathrm{DNA} / \mathrm{g}$. dry wt. mycelium decreased slightly (Fig. 3). Usually no pyruvic acid was excreted into the medium. In some anomalous batches of culture the concentration of pyruvate increased slightly (from $c .50 \mu \mathrm{g}$. $/ \mathrm{ml}$. to $\ngtr 200 \mu \mathrm{g}$. $/ \mathrm{ml}$.). In these batches also a simultaneous increase of respiration was observed. In these anomalous batches the yield of oxytetracycline was abnormally low $(800-1000 \mu \mathrm{g} . / \mathrm{ml}$. instead of the usual $1500-1800 \mu \mathrm{g} . / \mathrm{ml}$.). Microscopic preparations from this period of cultivation showed a majority of long Gram-negative filaments, later containing Gram-positive inclusions. These thin filaments grow from fragments of the primary mycelium; some of these fragments, however, do not germinate, so that they remain in the medium until the end of cultivation without changing. Occasionally a few long thick filaments of primary mycelium which had not undergone fragmentation were found.

Because of the biochemically and morphologically different character of this mycelium we call it secondary mycelium; in this stage there begins rapid production of oxytetracycline. At the end of the growth of secondary mycelium the culture contains 600-1000 $\mu$ g. oxytetracycline $/ \mathrm{ml}$.

The growth of secondary mycelium ceased as soon as ammonia and starch were depleted and the culture entered a stationary phase. Oxytetracycline continued, however, to be synthesized, so that in the stationary phase the maximum of production (1500-1800 $\mathrm{g}$. oxytetracycline $/ \mathrm{ml}$.) was reached. Up to $110 \mathrm{hr}$. of cultivation neither biochemical nor morphological signs of autolysis were observed. The mycelium in the stationary phase showed a gradual fragmentation of the secondary filaments so that towards the end of the cultivation period fragments of the secondary mycelium were most frequently found, although ungerminated fragments of primary mycelium and a few intact filaments of the primary mycelium were also found.

The course of metabolic changes during cultivation is shown in Figs. 2 and 3; the characteristics of various development phases are summarized in Table 2.

The development of the culture in seed-tanks, inoculated with $0.3-0.5 \%$ $(\mathrm{v} / \mathrm{v})$ of vegetative inoculum did not substantially differ from the development in production tanks with a $10 \%(\mathrm{v} / \mathrm{v})$ vegetative inoculum. The phase of logarithmic growth with the smaller inoculum lasted, however, c. 15-18 hr. longer. This was caused by the fact that different amounts of inoculum reached during their growth the same limiting values, which are probably controlled only by the composition of the medium and the characteristics of the fermentation equipment (Fig. 4).

\section{DISCUSSION}

As far as morphological characteristics of the mycelium are concerned, our findings agree roughly with the conclusions of Prokofieva-Belgorskaya et al. (1956). Contrary to these authors, however, we found only two types of growing mycelium, which we call primary and secondary, in agreement with 


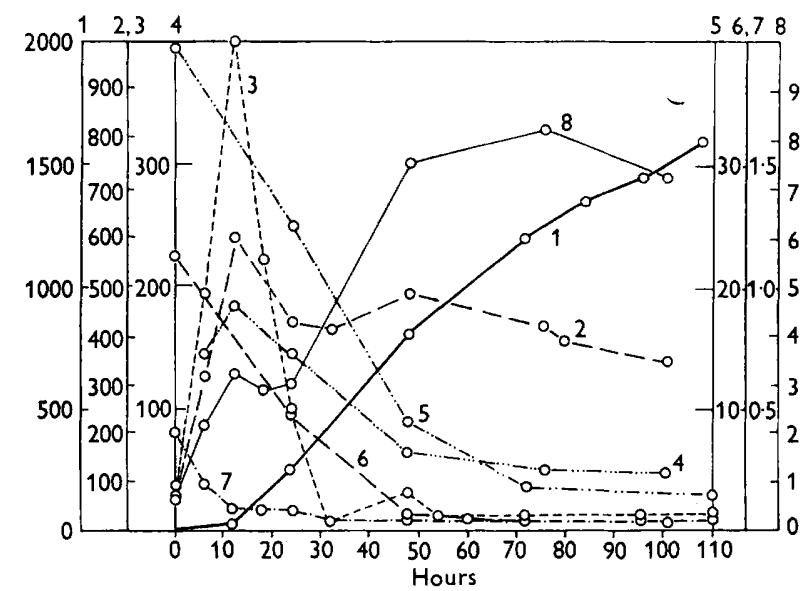

Fig. 2. Metabolic changes in the submerged culture of Streptomyces rimosus. The medium was inoculated with $10 \%(v / v)$ of a vegetative inoculum. 1 : concentration of oxytetracycline $(\mu \mathrm{g} . / \mathrm{ml}.) ; 2: \mathrm{O}_{2}$-uptake $\left(\mathrm{ml} . \mathrm{O}_{2} /\right.$ l. culture $\left./ \mathrm{hr}.\right) ; 3$ : concentration of pyruvate ( $\mu$ g. Na pyruvate $/ \mathrm{ml}$.); $4: Q_{\mathrm{O}_{2}}\left(\mathrm{ml} . \mathrm{O}_{2} / \mathrm{g}\right.$. dry wt. mycelium/hr.); 5: concentration of total carbohydrate after hydrolysis (mg. glucose $/ \mathrm{ml}$.); 6 : concentration of ammonianitrogen (mg./ml.); 7 : concentration of $\alpha$-amino-nitrogen (mg./ml.); 8 : dry wt. mycelium (mg./ml.).

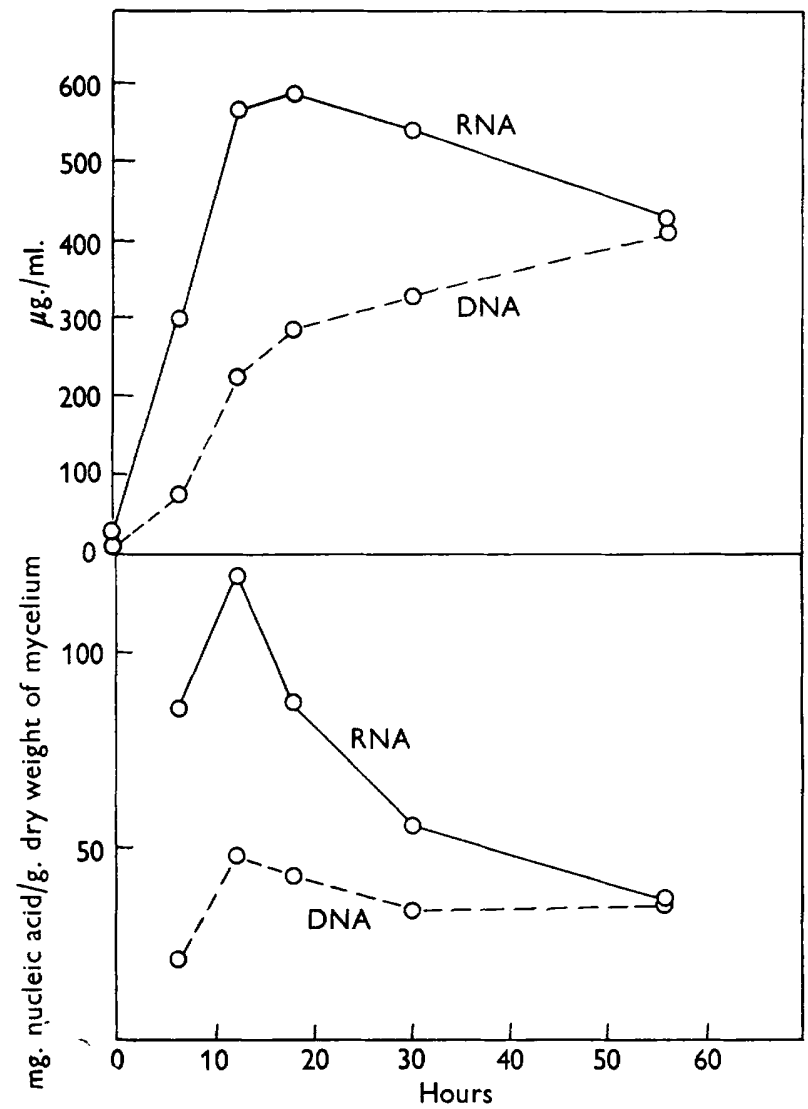

Fig. 3. Metabolism of nucleic acids in Streptomyces rimosus. The medium was inoculated with a $10 \%(\mathrm{v} / \mathrm{v})$ vegetative inoculum. Upper part: content of nucleic acids/unit of volume; lower part: content of nucleic acids/unit dry wt. mycelium. 
Table 2. Characters of the stages of development of Streptomyces rimosus in submerged culture

\begin{tabular}{|c|c|c|c|c|c|}
\hline & $\begin{array}{l}\text { Stage } 1 . \\
\text { Lag }\end{array}$ & $\begin{array}{l}\text { Stage } 2 . \\
\text { Growth of } \\
\text { primary } \\
\text { mycelium }\end{array}$ & $\begin{array}{c}\text { Stage } 3 . \\
\text { Fragmenta- } \\
\text { tion of } \\
\text { primary } \\
\text { mycelium }\end{array}$ & $\begin{array}{l}\text { Stage } 4 . \\
\text { Growth of } \\
\text { secondary } \\
\text { mycelium }\end{array}$ & $\begin{array}{l}\text { Stage 5. } \\
\text { Stationary } \\
\text { phase }\end{array}$ \\
\hline Duration & $\begin{array}{l}\text { About } 90 \mathrm{~min} \text {. } \\
\text { (only in } \\
\text { fermenta- } \\
\text { tions with a } \\
\text { small amount } \\
\text { of inoculum) }\end{array}$ & $\begin{array}{l}\text { 10-25 hr. } \\
\text { according to } \\
\text { amount of } \\
\text { inoculum }\end{array}$ & $10 \mathrm{hr}$. & $c .25 \mathrm{hr}$. & $\begin{array}{l}\text { The re- } \\
\text { mainder of } \\
\text { the cultiva- } \\
\text { tion period }\end{array}$ \\
\hline $\begin{array}{l}\text { Growth of the } \\
\text { mycelium }\end{array}$ & Nil & $\begin{array}{l}\text { Up to } 4-5 \mathrm{mg} . / \\
\text { ml. }\end{array}$ & Ceases & $\begin{array}{l}\text { Up to } \\
8-18 \mathrm{mg} . / \mathrm{ml} \text {. }\end{array}$ & Ceases \\
\hline Nucleic acids & Nil & $\begin{array}{l}\text { Maximum of } \\
\text { RNA; rapid } \\
\text { synthesis of } \\
\text { DNA }\end{array}$ & $\begin{array}{l}\text { RNA de- } \\
\text { creases; } \\
\text { DNA in- } \\
\text { creases } \\
\text { slowly }\end{array}$ & $\begin{array}{l}\text { RNA de- } \\
\text { creases; } \\
\text { DNA in- } \\
\text { creases } \\
\text { slowly }\end{array}$ & - \\
\hline $\begin{array}{l}\text { Morphology of } \\
\text { the mycelium }\end{array}$ & $\begin{array}{l}\text { Thick Gram- } \\
\text { positive } \\
\text { filaments }\end{array}$ & $\begin{array}{l}\text { Long thick } \\
\text { Gram-posi- } \\
\text { tive fila- } \\
\text { ments }\end{array}$ & $\begin{array}{l}\text { Fragmenta- } \\
\text { tion of thick } \\
\text { filaments; } \\
\text { single long } \\
\text { thin Gram- } \\
\text { negative } \\
\text { hyphae }\end{array}$ & $\begin{array}{l}\text { Thin Gram- } \\
\text { negative } \\
\text { filaments }\end{array}$ & $\begin{array}{l}\text { Fragmenta- } \\
\text { tion of thin } \\
\text { filaments }\end{array}$ \\
\hline Respiration & $\begin{array}{l}\text { Not mea- } \\
\text { surable }\end{array}$ & $\begin{array}{l}\text { Exponential } \\
\text { increase up } \\
\text { to } 500- \\
700 \mathrm{ml} . \mathrm{O}_{2} ! \\
\text { l. } / \mathrm{hr} .\end{array}$ & $\begin{array}{c}\text { Decreases } \\
\text { slightly }\end{array}$ & $\begin{array}{l}\text { Constant or } \\
\text { a very } \\
\text { slight in- } \\
\text { crease }\end{array}$ & $\begin{array}{l}\text { Decreases } \\
\text { slowly } 300- \\
400 \mathrm{ml} \text {. } \\
\mathrm{O}_{2} / \mathrm{l} / \mathrm{hr} .\end{array}$ \\
\hline$Q_{\mathrm{O}_{2}}$ & $\begin{array}{l}\text { Not mea- } \\
\text { surable }\end{array}$ & $\begin{array}{l}\text { Maximum } \\
\text { (average: } \\
137 \text { ml. }_{2} / \\
\text { g. dry wt. } \\
\text { mycelium/ } \\
\text { hr. }\end{array}$ & $\begin{array}{l}\text { Decreases } \\
\text { slightly }\end{array}$ & $\begin{array}{l}\text { Decreases } \\
\text { sharply } 20- \\
50 \mathrm{ml} . \mathrm{O}_{2} / \mathrm{g} . \\
\text { dry } \mathrm{wt} . / \mathrm{hr} .\end{array}$ & $\begin{array}{l}\text { Decreases } \\
\text { slowly }\end{array}$ \\
\hline $\begin{array}{l}\text { Consumption } \\
\text { of nutrients }\end{array}$ & Nil & $\begin{array}{l}\text { Amino-nitro- } \\
\text { gen and in- } \\
\text { organic- } \\
\text { phosphorus } \\
\text { almost com- } \\
\text { pletely used; } \\
\text { rapid con- } \\
\text { sumption of } \\
\text { sugars and } \\
\text { ammonia- } \\
\text { nitrogen }\end{array}$ & $\begin{array}{l}\text { Slowed-down } \\
\text { consump- } \\
\text { tion of } \\
\text { sugars and } \\
\text { ammonia- } \\
\text { nitrogen }\end{array}$ & $\begin{array}{l}\text { Rapid and } \\
\text { complete } \\
\text { depletion of } \\
\text { sugars and } \\
\text { ammonia- } \\
\text { nitrogen }\end{array}$ & - \\
\hline $\begin{array}{l}\text { Pyruvate } \\
\text { concentration }\end{array}$ & $24-30 \mu \mathrm{g} . / \mathrm{ml}$ & $\begin{array}{l}\text { Rapid in- } \\
\text { crease to } \\
800-1300 \mu \mathrm{g} . / \\
\text { ml. }\end{array}$ & $\begin{array}{l}\text { Rapid de- } \\
\text { crease to } \\
20-70 \mu \mathrm{g} . / \mathrm{ml} \text {. }\end{array}$ & $\begin{array}{l}\text { Sometimes a } \\
\text { slight in- } \\
\text { crease to } \\
200 \mu \mathrm{g} . / \mathrm{ml} . \\
\text { at the most }\end{array}$ & $\begin{array}{r}40 \mu \mathrm{g} . / \mathrm{ml} \text {. on } \\
\text { the average }\end{array}$ \\
\hline $\begin{array}{l}\text { Oxytetra- } \\
\text { cycline } \\
\text { production }\end{array}$ & Nil & Nil & $\begin{array}{l}\text { Start of } \\
\text { production }\end{array}$ & $\begin{array}{l}\text { 600-1000 } \mu \mathrm{g} .1 \\
\text { ml. }\end{array}$ & $\begin{array}{l}1500- \\
1800 \mu \mathrm{g} . / \mathrm{ml} .\end{array}$ \\
\hline
\end{tabular}


older literature. Our primary mycelium corresponds to the first generation of hyphae of Prokofieva-Belgorskaya et al., the secondary mycelium being identical with their second and third generations, which we were not able to differentiate in our experiments. It was to be mentioned that the cultures studied by the above authors produced only $c .400 \mu$ g. oxytetracycline $/ \mathrm{ml}$. whereas in our experiments $1500-1800 \mu \mathrm{g} . / \mathrm{ml}$. were obtained. The stage of

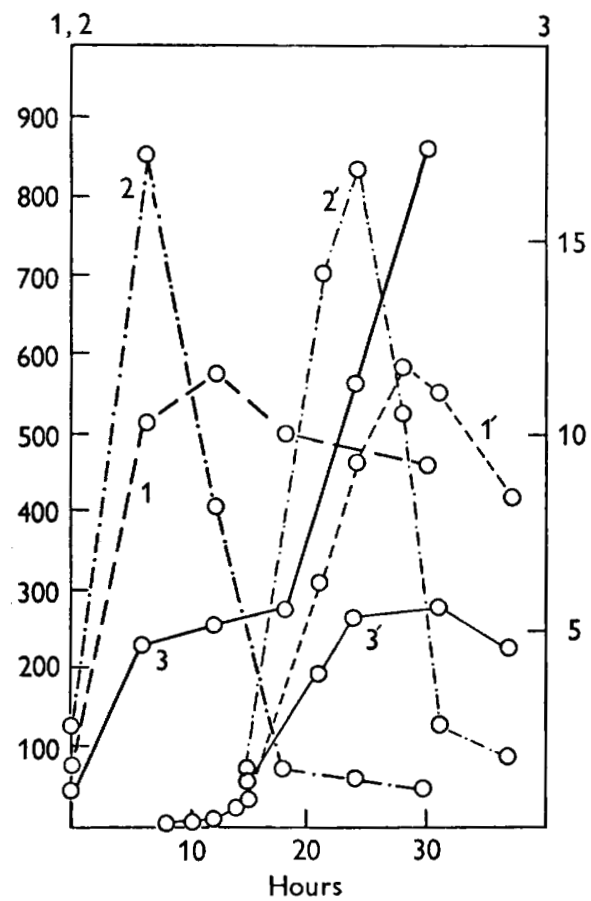

Fig. 4. Comparison of fermentations inoculated with different volumes of vegetative inoculum. 1, 2, $3=$ medium inoculated with $10 \%(\mathrm{v} / \mathrm{v})$ of vegetative culture; $1^{\prime}, 2^{\prime}$, $3^{\prime}=$ medium inoculated with $0.5 \%(v / v)$ of a vegetative culture. $1,1^{\prime}=\mathrm{O}_{2}$-uptake (ml. $\mathrm{O}_{2} /$ l. culture/hr.); 2, $2^{\prime}=$ concentration of pyruvate ( $\mu \mathrm{g}$. Na pyruvate/ml.); 3, $\mathbf{3}^{\prime}=$ dry wt. mycelium (mg./ml.).

disintegration of primary mycelium was designated as sporulation by Prokofieva-Belgorskaya et al. The physiological characteristics of this stage would suggest that this term is not a correct description of what happens. The fragmentation of the filaments is accompanied by only a small decrease of $\mathrm{O}_{2}$-uptake, and mycelium in this stage, when inoculated at $10 \%(\mathrm{v} / \mathrm{v})$ into fresh medium grows without any lag. These facts seem incompatible with the definition of spores. We therefore describe the disintegration of the filaments of primary mycelium as fragmentation in the sense of the definition of Krassilnikov (1950).

The metabolism of nucleic acids in Streptomyces aureofaciens was studied by Biffi et al. (1954) and by Guberniev, Ugoleva \& Torbochkina (1956a), and that of $S$. rimosus by Guberniev, Ugoleva \& 'Torbochkina (1956b). The course of 
nucleic acid metabolism according to our experiments is similar to the results obtained by Guberniev et al. (1956a) with the species $S$. aureofaciens; we cannot, however, confirm the completely irregular and wide variation of nucleic acid content, recorded by Guberniev et al. (1956b) for $S$. rimosus.

The growth curve of Streptomyces rimosus shows two periods of growth separated by a lag, so that by its form it is reminiscent of the phenomenon of 'diauxie' (Monod, 1942; Hinshelwood, 1946). This behaviour cannot be unequivocally explained on the basis of present experimental material and will be the subject of further study.

The growth of the secondary mycelium, which, contrary to the primary growth, takes place in a medium poor in amino acids, soluble inorganic phosphorus and probably also in oxygen, is limited only by the amount of ammonia and carbohydrates, as it continues until complete depletion of these nutrients.

The practical importance of a differentiation of the types of mycelium lies in the possibility of understanding the relations between the optimum composition of the medium and other fermentation conditions. When, for example, aeration conditions favourable for maximum growth of the primary mycelium are chosen, the concentration of ammonia nitrogen and starch must be correspondingly increased, because too great a part of these nutrients, which are indispensable for the growth of secondary myceliur, will have already been depleted in the stage of logarithmic growth of the primary mycelium. It has been observed several times that a composition of medium which gives satisfactory results in shaking flasks was inadequate in aerated large-scale vessels and addition of ammonium sulphate was then necessary to normalize the production of oxytetracycline.

From the point of view of antibiotic production the indirect dependance between the production of pyruvic acid and biosynthesis of oxytetracycline should be mentioned. These observations, for which some analogies may be found in the literature (Di Marco, Boretti, Julita \& Pennella, 1955), may be explained on the basis of Woodward's (1956) hypothesis about the synthesis of tetracycline antibiotics by condensation of several acetyl radicals. The probability of this hypothesis has recently been supported by a direct proof of a similar mechanism in the biosynthesis of griseofulvine, an antibiotic structurally related to the tetracyclines (Birch, Massy-Westropp, Rickards \& Smith, 1957). For the biosynthesis of oxytetracycline an excess of acetyl coenzyme $A$ is probably necessary. When the formation of active acetate from pyruvate is hindered by the lack of some necessary coenzyme or intermediate, pyruvate is excreted into the medium and is not utilized for the synthesis of antibiotic. 'This hypothesis needs, however, a direct experimental verification which would contribute to the solution of the mechanism of the biosynthesis of tetracycline antibiotics.

We wish to thank Docent M. Herold, Director of this Institute, for encouragement and stimulating discussions. 


\section{REFERENCES}

Baldacci, E. (1956). Il ciclo di vita degli attinomiceti osservato al microscopio elettronico. G. Microbiol. $1,512$.

Biffi, G., Boretti, G., Di Marco, A. \& Pennella, P. (1954). Metabolic behavior and chlortetracycline production by Streptomyces aureofaciens in liquid culture. Appl. Microbiol. 2, 288.

Birch, A. J., Massy-Westropp, R. A., Rickards, R. W. \& Smith, H. (1957). The conversion of acetic acid into griseofulvin in Penicillium griseofulvum Diercks. Proc. chem. Soc. p. 98.

Carvajal, F. (1947). Production of spores in submerged cultures by some Streptomyces. Mycologia, 39, 426.

Chargaff, E. \& Davidson, J. N. (1955). The Nucleic Acids. New York: Academic Press.

Cole, J. O. \& Parks, C. R. (1949). Semimicro-Kjeldahl procedure for control laboratories. Industr. Engng, Chem. 18, 61.

Di Marco, A., Boretti, G., Julita, P. \& Pennella, P. (1955). Researches on carbohydrate metabolism in Streptomyces aureofaciens in connection with chlortetracycline production. Commun. 3rd. Congr. Int. Biochim. Bruxelles.

Fiske, C. H. \& SubbaRow, Y. (1925). The colorimetric determination of phosphorus. J. biol. Chem. 66, 375.

Friedemann, T. E. \& Haugen, G. E. (1942). Pyruvic acid. Collection of blood for the determination of pyruvic and lactic acids. J. biol. Chem. 144, 67 .

Friedemann, T. E. \& Haugen, G. E. (1943). The determination of keto acids in blood and urine. J. biol. Chem. 147, 415 .

Guberniev, M. A., Ugoleva, N. A. \& Torbochkina, L. J. (1956a). Nucleic acids and phosphoric compounds in the mycelium of Actinomyces aureofaciens at different development stages. Antibiotiki, $1,8$.

Guberniev, M. A., Ugoleva, N. A. \& Torbochkina, L. J. (1956b). Content of nucleic acids and phosphoric compounds in the mycelium of Actinomyces rimosus at different development stages. Antibiotiki, 1, 25.

Hinshelwood, C. N. (1946). The Chemical Kinetics of the Bacterial Cell. Oxford: Clarendon Press.

Klieneberger-Nobel, E. (1947). The life cycle of sporing actinomyces as revealed by a study of their structure and septation. J. gen. Microbiol. $1,22$.

Krassilnikov, N. A. (1950). Actinomycetes-antagonists and anti-microbial agents. Moscow and Leningrad: Izdatelstvo Akademii Nauk SSSR.

Monastero, F., Means, J. A., Grenfell, 'T. C. \& Hedger, F. H. (1951). Terramycin: Chemical methods of assay and identification. J. Amer. pharm. Ass. (Sci. ed.), 40, 241.

Monod, J. (1942). La croissance des cultures bactériennes. Paris: Herman \& Cie.

NeČÁseK, J. \& Lokvenc, F. (1956). The production of oxytetracycline in laboratory scale. Preslia, 28, 99.

Ogur, M. \& Rosen, G. (1950). The nucleic acids of plant tissues. I. The extraction and estimation of desoxypentose nucleic acid and pentose nucleic acid. Arch. Biochem. 25, 262.

Prokofieva-Belgorskaya, A. A., Pestiereva, G. D. \& Rudaya, S. M. (1956). The properties of growth and development of Actinomyces rimosus in submerged culture. Microbiology, Moscow, 25, 668.

Schroeder, W. A., KAY, L. M. \& Mrlls, R. S. (1950). Quantitative determination of amino acids by iodometric titration of their copper salts. Reinvestigation of the method of Pope and Stevens. Analyt. Chem. 22, 760.

Scotti, T. \& Zocchi, P. (1955). Studie della struttura del micelio de Streptomyces aureofaciens in coltura sommersa. G. Microbiol. 1, 35. 
TAUBer, H. (1955). Separation of $\alpha$-keto acids dinitrophenyl-hydrazones by paper electrophoresis and their colorimetric determination. Analyt. Chem. 27, 287.

Umbreit, W. W., Burris, R. H. \& Stauffer, J. F. (1951). Manometric Techniques and Tissue Metabolism. Minneapolis: Burgess Publishing Co.

Woodward, R. B. (1956). Neuere Entwicklungen in der Chemie der Naturstoffe. Angerv. Chem. 68, 13.

(Received 5 July 1957) 